\title{
Inhalt der 1. Lieferung
}

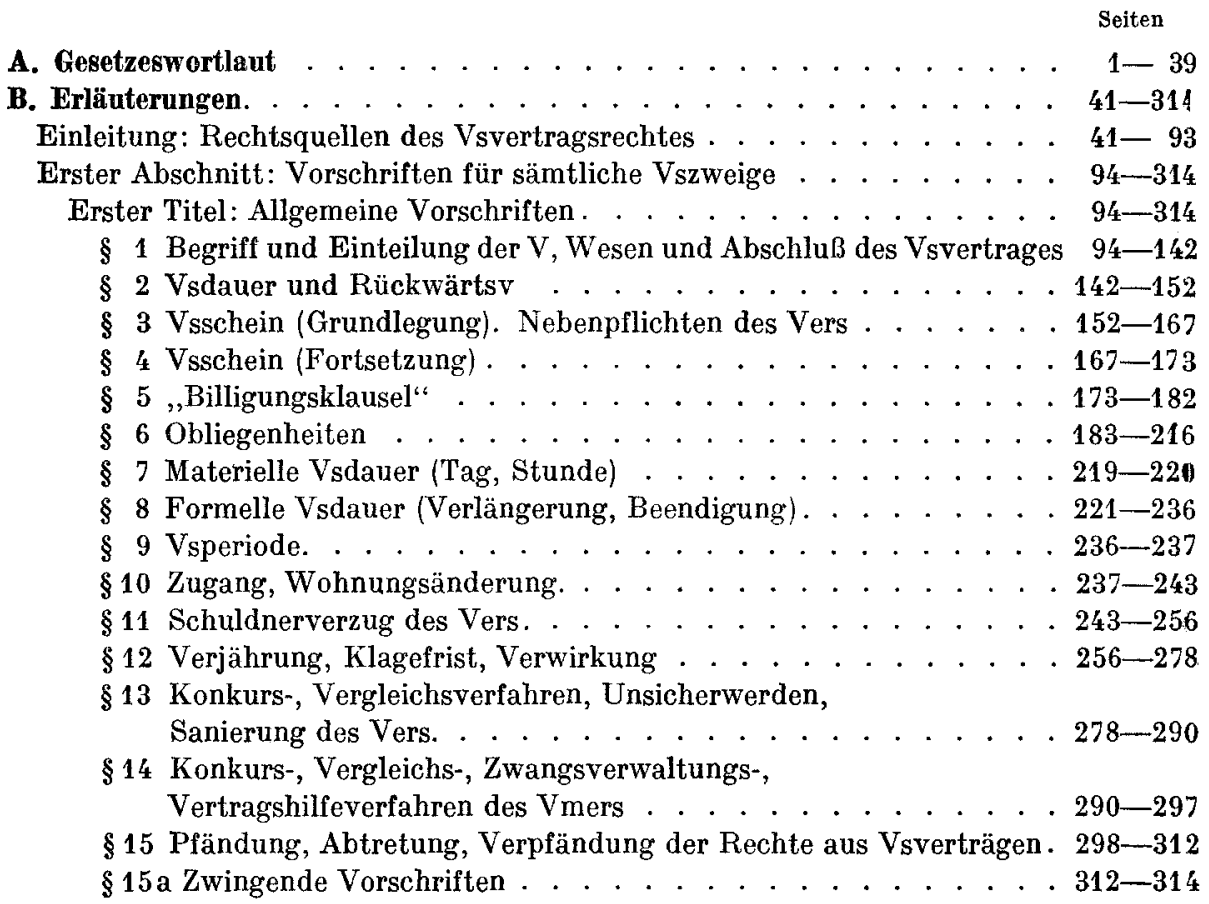

\footnotetext{
Abkürzungen

Die Abkürzungen für die gebräuchlichsten Allgemeinen Versicherungsbedingungen (AVB) sind eingeführt in der Einl. Anm. 20.

Das wichtigste Schrifttum ist mit der benutzten Zitierweise angeführt in der Einl. Anm. 39. - Ist ein Werk mit dem Zusatz a. a. O. zitiert, so ist der genaue Fundort aus den Schrifttumsangaben des betreffenden Abschnitts zu entnehmen.

Ferner bedeuten: $\mathrm{V}=$ Versicherung, $\mathrm{Ver}=$ Versicherer, Vmer $=$ Versicherungsnehmer, Vter $=$ Versicherter.

Ein ausführliches Abkürzungsverzeichnis wird der letzten Lieferung beigefügt sein.
} 